\title{
Characterization of the Luminescent, Homoleptic, Three-Coordinate, Water Soluble Au(I) Complex of Trisulfonated Triphenylphosphine (TPPTS) as the Cesium Salt, $\mathrm{Cs}_{8}\left[\mathrm{Au}(\mathrm{TPPTS})_{3}\right] \cdot 5.25 \mathrm{H}_{2} \mathrm{O}$
}

\author{
John P Fackler, Jr* and Tiffany A. Grant \\ Laboratory for Molecular Structure and Bonding, Department of Chemistry, Texas A\&M University, College Station, \\ TX 77843-3255, USA \\ Brian E Hanson \\ Department of Chemistry, Virginia Polytechnic Institute and State University, Blacksburg, VA 24061-0212, USA \\ Richard J Staples \\ Department of Chemistry and Chemical Biology, Harvard University, Cambridge, MA 02138, USA
}

Received: 9 February 1999

The homoleptic metal-TPPTS complex $\mathrm{Cs}_{8}\left[\mathrm{Au}(\mathrm{TPPTS})_{3}\right] \cdot 5.25 \mathrm{H}_{2} \mathrm{O}$ has been characterized structurally. The $x$-ray data for the triclinic crystal, $P$-1, with cell constants $a=13.7003(4), b=18.0001(6), c=18.2817(2)$, $\alpha=100.249(2), \beta=99.593(2), \gamma=109.818(2)$ shows trigonal planar Au(I) centers coordinated by three TPPTS ligands having Au-P distances equal to 2.374(6), 2.394(5), and 2.417(5)A. The structure shows a complex network of bonding involving the $\mathrm{Cs}^{+}$ions, the sulfate groups of the ligand, and $\mathrm{H}_{2} \mathrm{O}$ solvent molecules. The $\left[\mathrm{Au}(\mathrm{TPPTS})_{3}\right]^{8}$ luminesces in the solid state and in aqueous solution with a broad emission at ca $520 \mathrm{~nm}$ which is quenched by $\mathrm{O}_{2}$. and other small molecules. The forbidden singlet to triplet absorption at ca $552 \mathrm{~nm}$ with $\varepsilon \sim 0.8 \mathrm{Lmol}^{-1} \mathrm{~cm}^{-1}$ is also observed.

Phosphine complexes of transition metals are important in homogeneous catalysis $(1,2)$. During the past few years 'green-chemistry' has dictated that new solvents and catalysts be found that minimize the use of toxic chemicals. Processes that function under less hazardous reaction conditions (3) and with benign solvents have been sought. The use of water soluble phosphine catalysts is part of this green chemistry trend. A 1994 NATO workshop brought focus to this effort (4). The successful use of water-soluble sulfonated phosphine catalysts in hydroformylation, hydrogenation, and coupling reactions (5) has been especially important. These systems have provided a simple means of separating the catalyst from the product soluble in the non-aqueous layer. The trisulfonated triphenylphosphine, TPPTS, tris(msulfophenyl)phosphine, is one of the more commonly employed phosphines in biphasic catalyst systems (6).

Luminescence studies of $\mathrm{Au}(\mathrm{I})$ compounds have produced some interesting results recently $(7,8)$. Photoluminescence (9) is observed in several classes of $\mathrm{Au}(\mathrm{I})$ compounds, including three-coordinate complexes $(10,11)$. Trigonal coordination about the gold center leads to an excited state which produces a long-lived ( $\mu s)$ metal-centered phosphorescence (12). With the use of water soluble phosphines such as 


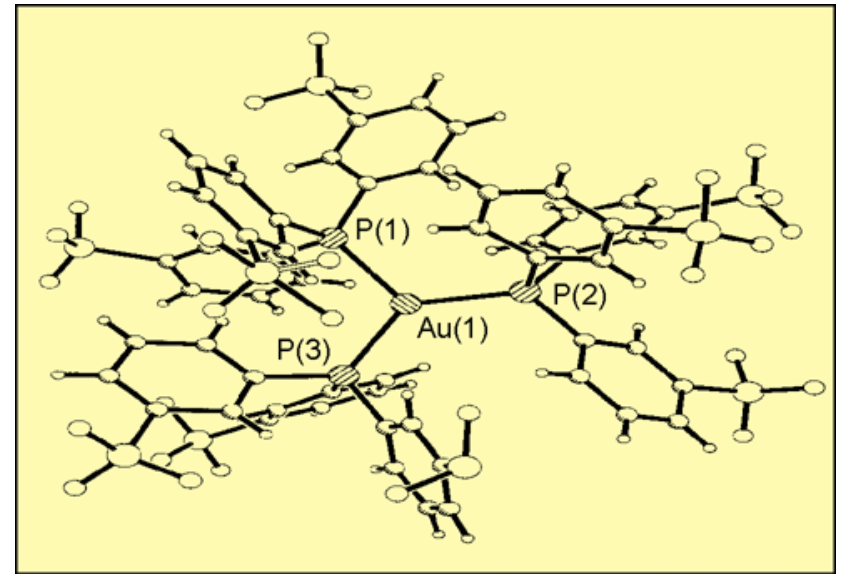

Figure 1 Molecular structure of the anion $\left[A u(T P P T S)_{3}\right]^{8-}$. The $\mathrm{Cs}^{+}$ions and water molecules are omitted for clarity

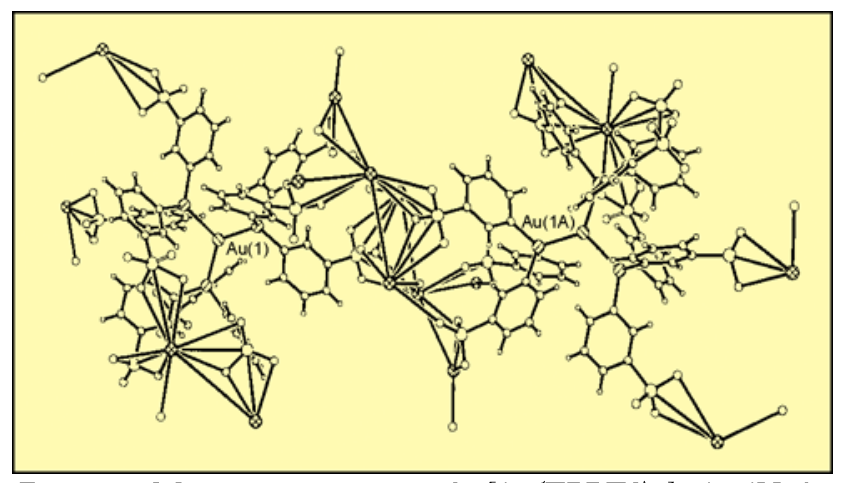

Figure 2 Molecular structure of $\mathrm{Cs}_{8}\left[\mathrm{Au}(\mathrm{TPPTS})_{3}\right] \cdot 5.25 \mathrm{H}_{2} \mathrm{O}$

1,3,5-triaza-7-phosphaadamantane (TPA) and TPPTS (13) aqueous solution phosphorescence is observed and has been suggested to be associated with a 3coordinate, tris-phosphine species. However, prior to this work no strictly 3-coordinate, luminescent, water soluble tris-phosphine complex of $\mathrm{Au}(\mathrm{I})$ had been structurally characterized. Furthermore, no homoleptic metal complexes of the important TPPTS ligand have been characterized structually and there are few examples of structurally characterized metal complexes containing this ligand $(14-16)$.

The compound $\mathrm{Cs}_{8}\left[\mathrm{Au}(\mathrm{TPPTS})_{3}\right] \cdot 5.25 \mathrm{H}_{2} \mathrm{O}$ (1) which exhibits luminescence in the solid state and in aqueous solution, was synthesized by the addition of three equivalents of the cesium salt of TPPTS to one equivalent of $\mathrm{Au}(\mathrm{THT}) \mathrm{Cl}$ in a $\mathrm{H}_{2} \mathrm{O} / \mathrm{CH}_{2} \mathrm{Cl}_{2}$ (1:1) solution. Crystals of $\mathbf{1}$ were obtained from a water solution of the complex (17). The complex crystallizes in the triclinic space group P-1 with two formula units in the unit cell. The lattice contains discrete
$\left[\mathrm{Au}(\mathrm{TPPTS})_{3}\right]^{8-}$ units, Figure 1, that are interconnected through a complex network of bonds between the sulfonate groups and the cesium cations, Figure 2.

The coordination about $\mathrm{Au}(\mathrm{I})$ approximates $\mathrm{D}_{3 \mathrm{~h}}$ symmetry, excluding the phenyl rings. The $\mathrm{Au}-\mathrm{P}$ bond lengths are 2.374(6), 2.394(5), and 2.417(5) A and are similar to those found in other gold-phosphine complexes. This same general ligand geometry (presumably ligand dictated) has been suggested (18) for the important hydroformylation catalyst [RhH(CO)TPPTS] used by Ruhrchemie AG. The sum of the P-Au-P angles is equal to $360^{\circ}$. The diameter of a molecule is on the order of $15 \mathrm{~A}$ with $8 \mathrm{Cs}^{+}$ions associated with the nine sulfate groups. The carbon and oxygen atoms were refined isotropically with some disorder the oxygen atoms of the sulfate groups and water molecules.

The cesium salt of TPPTS was used (19) to obtain single crystals of $\mathbf{1}$. The large size of $\mathrm{Cs}^{+}$and its polarizability compared to the more common sodium salt of the ligand appear to be important factors in the crystallization in which $\mathrm{CsCl}$ is eliminated (Equation 1). Crystallization using the sodium salt of TPPTS was unsuccessful.

$$
\left.\mathrm{Cs}_{9}\left[\mathrm{Au}(\mathrm{TPPTS})_{3}\right] \mathrm{Cl} \rightarrow \mathrm{Cs}_{8}\left[\mathrm{Au}_{\mathrm{uPPTS}}\right)_{3}\right]+\mathrm{CsCl}(1
$$

Although gold(I) is commonly two-coordinate there are a few structural reports of three-coordinate $\mathrm{Au}(\mathrm{I})$ complex (20), few of these compounds have been investigated for photoluminescence. Two crystal structures of water soluble, 3-coordinate $\mathrm{Au}(\mathrm{I})$ complexes of alkylated (at N) 1,3,5 triaza-7phosphaadamantane $(21,22)$ have been described but these materials contain iodide weakly interacting with the $\mathrm{Au}(\mathrm{I})$ centers at $\sim 2.9 \AA$. Another water soluble, nearly planar $\mathrm{AuP}_{3}$ complex, uses the ligand diphenylhydroxymethylphosphane (23).

Compound $\mathbf{1}$ is the first metal complex structurally characterized which has a homoleptic arrangement of the commercially important TPPTS ligands. TPPTS complexes and others (24) with sulfonated phosphine ligands tend to crystallize in layers consisting of hydrophilic planes of sulfonate groups, cations, and solvent with hydrophobic planes containing the metal complex and the ligands. A similar arrangement is found here with the trigonally planar Au(I) TPPTS complex. It is isoelectronic and presumably structurally like the $\operatorname{Pd}(0)$ catalysts that have been used for carbonylation of aryl halides (25), as well as the $\mathrm{Rh}(\mathrm{I})$ catalysts mentioned above (2). The 
${ }^{31} \mathrm{P}\left\{{ }^{1} \mathrm{H}\right\}$ NMR spectrum of $\left[\mathrm{Au}(\mathrm{TPPTS})_{3}\right]^{8-}$ shows a dynamic behavior similar to the behavior reported for the $\operatorname{Pd}(0)$ system. With $\left[\mathrm{Au}(\mathrm{TPPTS})_{3}\right]^{8-}$, a broad signal at $43.5 \mathrm{ppm}$ is observed at room temperature which is the weighted average signal for $\left[\mathrm{Au}(\mathrm{TPPTS})_{3}\right]^{8-}$, $\left[\mathrm{Au}(\mathrm{TPPTS})_{2}\right]^{5-}$ and free TPPTS (at - $5 \mathrm{ppm}$ ), seen as sharp peaks at low temperature (in $\mathrm{CD}_{3} \mathrm{OD}$ ), with the $\left[\mathrm{Au}(\mathrm{TPPTS})_{3}\right]^{8-}$ dominating. As further equivalents of the TPPTS ligand are added to a solution of the complex, this latter signal shifts upfield, as observed in the $\operatorname{Pd}(0)$ system, indicating chemical exchange.

The luminescence (26) exhibited by $\mathbf{1}$ in the solid state and in aqueous solution is illustrated in Figure 3. The solid state complex emits at $494 \mathrm{~nm}$ and is blueshifted from the emission observed in aqueous solution at $513 \mathrm{~nm}$. This $750 \mathrm{~cm}^{-1}$ difference in the peak maximum presumably is related to small differences in the strength of the Au-P bonds in the two phases. The overall similarity of the spectra confirms that the same 3 -coordinate species is the luminescent species in both phases.

The forbidden electronic absorption between the singlet ground-state and the triplet excited state in $\left[\mathrm{Au}(\mathrm{TPPTS})_{3}\right]^{8-}$ can be observed in aqueous solution at room temperature. The absorption has a maximum at $552 \mathrm{~nm}\left(\varepsilon_{\max } \sim 0.8 \mathrm{ML}^{-1} \mathrm{~cm}^{-1}, f \sim 1.5 \times 10^{-5}\right)$ and a width at half-height of about $4015 \mathrm{~cm}^{-1}$. The oscillator strength is in a range expected (27) for spin forbidden transitions. The shift of $\sim 1800 \mathrm{~cm}^{-1}$ to higher energy for the emission maximum from the triplet excited state, compared with the absorption from the singlet ground state presumably reflects the presence of stronger $\mathrm{Au}-\mathrm{P}$ bonds in the excited state. As reported previously (13) the $\mathrm{HOMO}$ for 3-coordinate $\mathrm{AuP}_{3}$ complexes in $\mathrm{D}_{3 \mathrm{~h}}$ symmetry is largely an antibonding $\mathrm{e}^{\prime}\left(\mathrm{d}_{\mathrm{xy}}, \mathrm{d}_{\mathrm{x} 2-\mathrm{y} z}\right)$ orbital while the LUMO is a nonbonding a" $\left(p_{z}\right)$ orbital. The $\mu$ s lifetime of the excited state allows for a relaxation and strengthening of the $\mathrm{Au}-\mathrm{P}$ bonds to accommodate the removal of electron density from the antibonding HOMO (28).

Energy transfer and electron transfer quenching has been demonstrated for some photoluminescent metal complexes of $\mathrm{Au}(\mathrm{I})(29,30)$. Excited state quenching reactions also occur with photoluminescent $\left[\mathrm{Au}(\mathrm{TPPTS})_{3}\right]^{8-}$ in aqueous solution. Dioxygen reversibly quenches luminescent $\mathrm{Au}(\mathrm{I})$ complexes in the solid state in thin films of gold containing polymers $(31,32)$. A reversible quenching process also occurs in aqueous solutions of $\left[\mathrm{Au}(\mathrm{TPPTS})_{3}\right]^{8-}$. Figure 4 shows the emission spectrum of $\left[\mathrm{Au}(\mathrm{TPPTS})_{3}\right]^{8-}$ in a de-oxygenated aqueous solution and in an aqueous solution saturated with $\mathrm{O}_{2}$; before and after bubbling $\mathrm{N}_{2}(\mathrm{~g})$ through the solution for

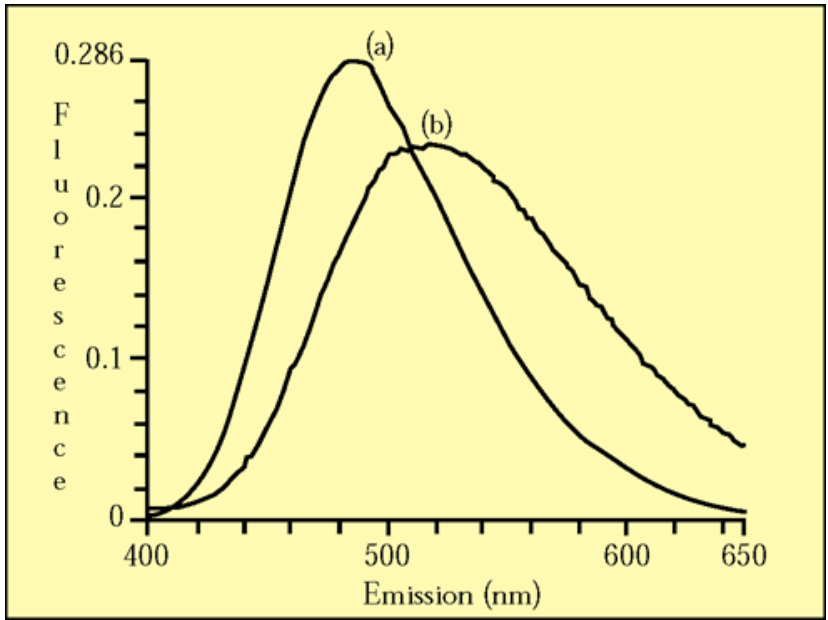

Figure 3 The emission spectra of $\mathrm{Na}_{8}\left[\mathrm{Au}(\mathrm{TPPTS})_{3}\right]$ (a) as a solid at room temperature and (b) in aqueous solution, excited at $335 \mathrm{~nm}$. The ionic strength is held constant in solution with $0.5 \mathrm{M} \mathrm{NaCI}$

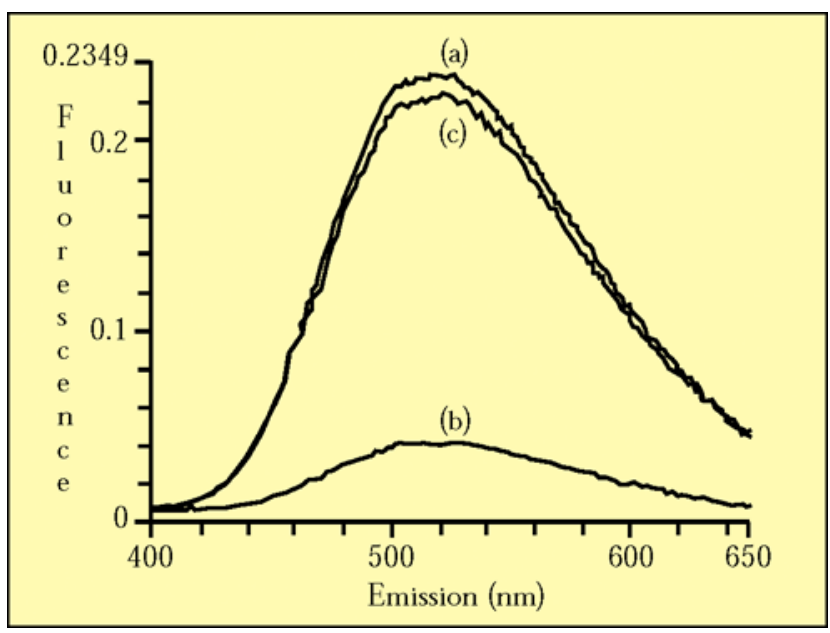

Figure 4 The reversible emission quenching of $\mathrm{Na}_{8}\left[\mathrm{Au}(\mathrm{TPPTS})_{3}\right]$ by $\mathrm{O}_{2}(\mathrm{~g})$ in aqueous solution: (a) $100 \% \mathrm{~N}_{2}(g)$ purge; (b) $100 \% \mathrm{O}_{2}(g)$ purge; (c) $100 \% \mathrm{~N}_{2}(g)$ purge after oxygenation. Spectra were excited at $335 \mathrm{~nm}$

15 minutes. This reversibility may be important for potential application of these systems as photoluminescent sensors. Small molecules such as nitric oxide, sulfur dioxide, and alkyl halides, and some metal ions such as $\mathrm{Cu}^{2+}$ also quench the emission in aqueous solution. These results will be reported in detail elsewhere.

\section{ACKNOWLEDGMENT}

The support of the Robert A Welch Foundation is gratefully acknowledged. 


\section{ABOUT THE AUTHORS}

John P Fackler, Jr is Distinguished Professor of Chemistry at Texas A\&M University and amongst his more than 280 publications there are over 100 papers relating to gold chemistry. Tiffany A Grant studied for her $\mathrm{PhD}$ with Fackler on the luminescent properties of gold(I) complexes and developed the crystallization of the water soluble phosphine complex reported here. Brian E Hanson is Professor of Chemistry at Virginia Polytechnic Institute and State University and is an expert in the use of biphasic systems for hydroformylation which involve sulfonated phosphine complexes of metal ions. Richard J Staples is staff crystallographer for the Chemistry Department at Harvard University and has structurally characterized over 50 gold compounds.

\section{REFERENCES}

1 'Homogeneous Catalysis with Metal Phosphine Complexes', ed. L.H. Pignolet, Plenum Press, 1983

2 'Aqueous-Phase Organometallic Catalysis', ed. B. Cornils and WA. Hermann, Wiley-VCH, 1998

3 C. Washam, 'Reaction Times', American Chemical Society: Washington, D.C., April 1998

4 I.T. Horváth and F. Joó, 'Aqueous Organometallic Chemistry and Catalysis', Kluwer Acad, Dordrecht, 1995

5 C. Amatore, E. Blart, J.P. Genêt, A. Jutand, S. Lemaire-Audoire and M. Savignac, J. Org. Chem, 1995, 60, 6829

6 F. Monteil, L. Miquel, R. Queau and P. Kalck, in reference 3, pp.131-147

7 J.C. Vickery, M.M. Olmstead, E.Y. Fung and A.L. Balch, Angew. Chem. Int. Ed. Engl, $1997,36,1179$

8 M.A. Mansour, W.B. Connick, R.J. Lachicotte, H.J. Gysling and R. Eisenberg, J. Am. Chem. Soc., 1998, 120, 1329

9 M.N.I. Khan, R.J. Staples, C. King, J.P. Fackler; Jr and R.E.P. Winpenny, Inorg. Chem, $1993,32,5800$

10 C. King, M.N.I. Khan, R.J. Staples and J.P. Fackler, Jr, Inorg. Chem., 1992, 31, 3236

11 T.M. McCleskey and H.B. Gray, Inorg. Chem., 1992, 31, 1734
12 J.M. Forward, J.P., Fackler, Jr and Z. Assefa, in 'Optoelectronic Properties of Inorganic Compounds', ed. D.M. Roundhill and J.P. Fackler, Jr, Plenum Press, 1999, pp.195-229

13 J.M. Forward, Z. Assefa and J.P. Fackler, Jr, J. Am. Chem. Soc, 1995, 117, 9103

14 D.J. Darensbourg, C.J. Bischoff and J.H. Reibenspies, Inorg. Chem., 1991, 30, 1144

15 T. Bartik, B. Bartik, B.E. Hanson, K.H. Whitmire and I. Guo, Inorg. Chem., 1993, 32, 5833

16 D.J. Darensbourg, T. J. Decuir and J.H. Reibenspies, Aqueous Organometallic Chemistry and Catalysis', ed. I.T. Horrath and F. Joo, NATO ASI Series, Kluwer Academic Publishers, 1995, p. 61

17 The crystal structure of $\mathbf{1}$ was solved and refined in the triclinic P-1 space group. Pale yellow crystals were obtained from a water solution. Crystallographic data are given as $\mathrm{a}, \mathrm{b}, \mathrm{c}(\AA) ; \alpha, \beta, \gamma(\mathrm{deg})$; volume $\left(\AA^{3}\right), \mathrm{Z}, \mathrm{R} 1$ [I>2sigma $\left.(\mathrm{D})\right]$, and GOF: $\mathrm{a}=13.7003(4)$, $18.0001(6), 18.2817(2) ; 100.249(2), 99.593(2), 109.818(2) ; 4046.3(2), 2,0.0659,0.946$

18 B. Cornils and E.G. Kuntz, in reference 2, p. 276

19 J. Kang, Masters Thesis, Virginia Polytechnic Institute and State University, Blacksburg, VA, 1997

20 M.C. Gimeno and A. Laguna, Chem. Rev, 1997, 97, 511

21 J.M. Forward, J.P. Fackler, Jr and R.J. Staples, Organometallics, 1995, 14, 4194

22 J.M. Forward, R.J. Staples, C.W. Liu and J.P. Fackler, Jr, Acta Cryst. Sect. C, 1997, 195

23 D.E. Berning, K.V. Katti, C.L. Barnes and W.A. Volkert, Chem. Ber/Recueil, 1997, 130, 907

24 A.L. Casalunuovo and J.C. Calabrese, J. Am. Chem. Soc, 1990, 112, 4324

25 F. Monteil and P.J. Kalck, Organomet. Chem., 1994, 482, 45-51

26 Photoluminesce data were obtained using a SLM AMINCO, Model 8100 spectrofluorometer with a xenon lamp. Radiation was filtered through a $0.10 \mathrm{M} \mathrm{KNO}_{2}$ solution. Solution measurements, unless stated otherwise, were done in $0.50 \mathrm{M} \mathrm{NaCl}$ formed with doubly distilled water, deoxygenated by a $15 \mathrm{~min} \mathrm{~N}_{2}$ (g) purge.

27 T.M. Dunn, in 'Modern Coordination Chemistry', ed. J. Lewis and R.G. Wilkins, Interscience, 1969 , p. 280

28 The shift observed suggests a strengthening of the Au-P bonds in the excited state by about $5 \mathrm{kcal}$.

29 C.-M. Che, H.-L. Kwong, C.-K. Poon and V. W.-W. Yam, J. Chem. Soc, Dalton Trans, 1990,3215

30 D. Li, C.-M. Che, H.-L. Kwong and V.H.-H. Yam,. J. Chem. Soc, Dalton Trans., 1992, 3325

31 A. Mills, A. Lepre, B.R.C. Theobald, E. Slade and B. Murrer, Anal. Chem, 1997, 69, 2842 .

32 A. Mills, A. Lepre, B.R.C. Theobald, E. Slade and B.A. Murrer, Gold Bull., 1998, 31, 68
Continued from page 11

32 A. Ueda, T. Nakao, M. Azuma and T. Kobayashi, Catal. Today, 1998, 45, 135

33 M. Haruta, S. Tsubota, T. Kobayashi, H. Kageyama, M.J. Genet and B. Delmon, J. Catal., 1993, 144, 175

34 A. Ueda, T. Onshima and M. Haruta, Appl. Catal. B, 1997, 12, 81

35 G. Zhang, et al, Appl. Catal. B, 1992, 1, L15

36 H. Hirabayashi, H. Yahiro, N. Mizuno and M. Iwamoto, Chem. Lett., 1992, 2235

37 M. Haruta, T. Takase, T. Kobayashi and S. Tsubota, in 'Catalytic Science and Technology', ed. S. Yoshida, N. Takezawa and T. Ono, Kodansha, Tokyo, 1991, 1, 331; D.A.H. Cunningham, T. Kobayashi, N. Kamijo and M. Haruta, Catal. Lett., 1994, 25, 257

38 Y. Li and J.N. Armor, J. Catal., 1994, 145, 1
39 T. Miyadera, Appl. Catal. B, 1993, 2, 199

40 J.N. Armor, Catal. Today, 1995, 26, 147

41 A. Obuchi, A. Ohi, M. Nakamura, A. Ogata, K. Mizuno and H. Ohuchi, Appl. Catal. $B, 1993,2,71$

42 H. Hamada, Catalysis Surveys from Japan, 1997, 1, 53

43 E. Kikuchi and K. Yogo, Catal. Today, 1994, 22, 73

44 R. Burch and PJ. Millington, Appl. Catal. B, 1993, 2, 101

45 R. Burch, P. J. Millington and A.P. Walker, Appl. Catal. B, 1994, 4, 65

46 M. Ogura, Y. Sugiura, M. Hayashi and E. Kikuchi, Catal. Lett., 1996, 42, 185

47 A. Ueda, T. Kobayashi and M. Haruta, Shokubai (Catalysis \& Catalysts), 1997, 39, 122

47 M. Misono, Cattech, 1998, 3, 53 